Eastern Illinois University

The Keep

Faculty Research and Creative Activity

Geography/Geology

January 2008

\title{
How Human and Natural Driving Forces Affect Pheasants and Pheasant Hunting in South Dakota
}

Chris Laingen

Eastern Illinois University, crlaingen@eiu.edu

Follow this and additional works at: http://thekeep.eiu.edu/geoscience_fac

Part of the Geology Commons

\section{Recommended Citation}

Laingen, Chris, "How Human and Natural Driving Forces Affect Pheasants and Pheasant Hunting in South Dakota" (2008). Faculty Research and Creative Activity. 11.

http://thekeep.eiu.edu/geoscience_fac/11

This Article is brought to you for free and open access by the Geography/Geology at The Keep. It has been accepted for inclusion in Faculty Research and Creative Activity by an authorized administrator of The Keep. For more information, please contact tabruns@eiu.edu. 


\section{How Human and Natural Driving Forces Affect Pheasants and Pheasant Hunting in South Dakota}

Chris Laingen

\section{Introduction}

The percentage of Americans who actively participated in hunting declined 7 percent from 1960 to 2005 (U.S. Fish and Wildlife Service 2008a, b, c, d). During the same time the number of pheasant hunters in South Dakota increased by over 34 percent (South Dakota Game, Fish, and Parks 2008b). Even during the fall of 2001, just one month after September 11, the number of out-of-state hunters who traveled to South Dakota increased from the previous year (Woster 2001a). Many changed their travel plans from flying to driving, but still made their October pilgrimage (Figure 1).

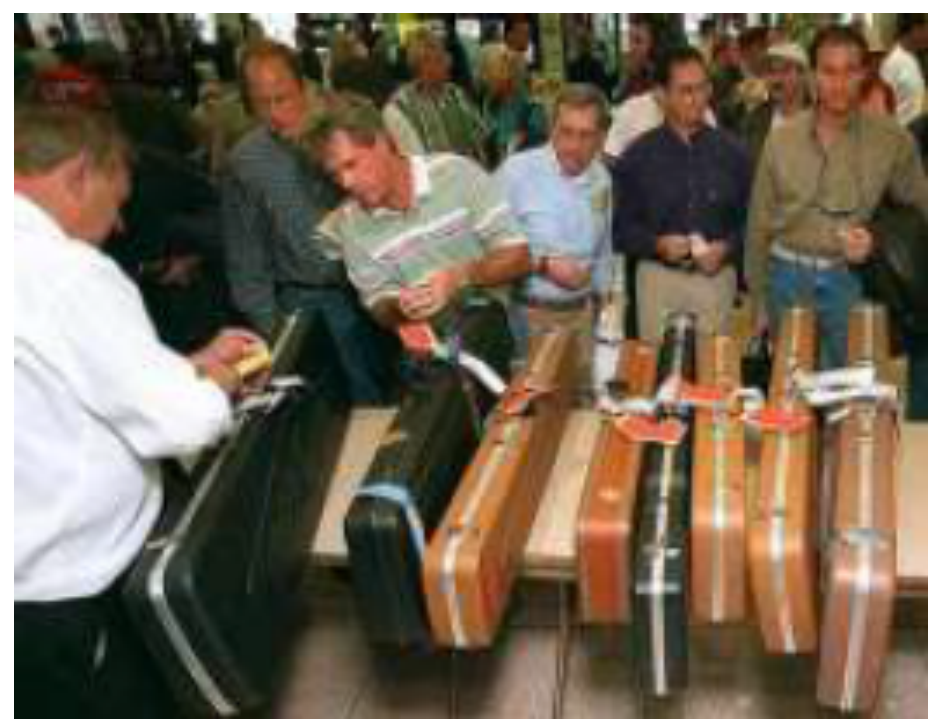

Figure 1: Where's my gun? Out-of-state pheasant hunters arriving at the Sioux Falls Regional Airport on opening weekend of pheasant season. Photo used with permission of the Sioux Falls Argus Leader.

In 2002, for the first time since 1919, non-resident hunters outnumbered residents (Figure 2), and this gap continues to widen each year. In 2007, 103,231 non-South Dakotans (13 percent of the total state population) came to the state to hunt pheasants. Pheasant hunting is to South Dakota what golfing is to Scotland, with companies offering all-inclusive hunting trips to workers and clients (Shouse 2003). Business deals are struck in a field of switchgrass by men dressed in blaze orange as frequently as they are on a tee box (Merry 2003). South Dakota, along with other surrounding states such as North Dakota, has reaped the economic benefits of its large pheasant population (Bangsund, Hodur, and Leistritz 2004). Each year, the 
growing number of non-resident hunters contributes nearly $\$ 180$ million to the state's economy (South Dakota Game, Fish, and Parks 2008a)[1].

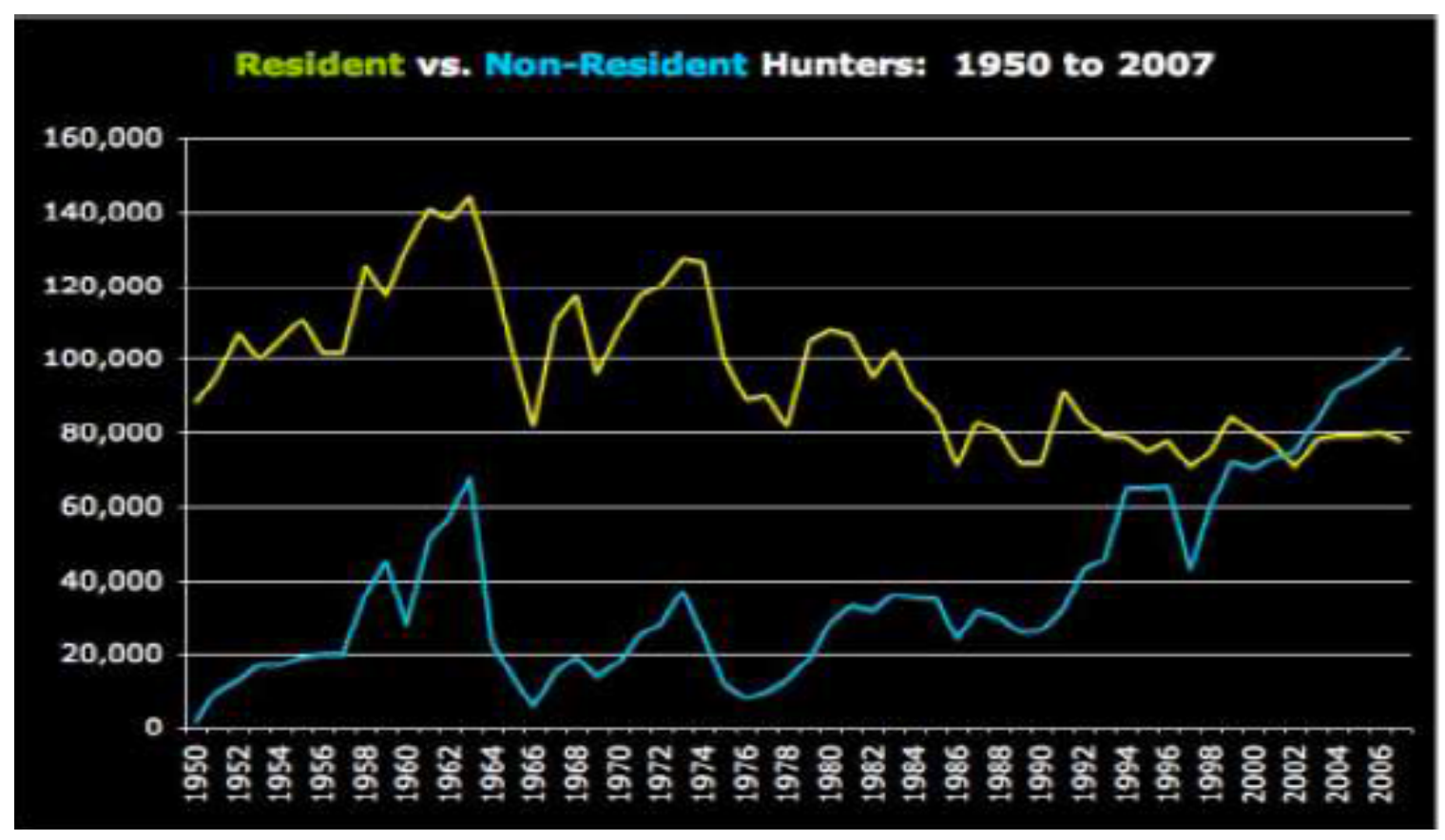

Figure 2: Residents (green line) are overtaken by non-resident hunters (blue line). Source: South Dakota Game, Fish, and Parks 2008b.

The ring-necked pheasant (Phasianus colchicus) was first successfully introduced into the U.S. in the Willamette Valley of Oregon in 1881. It took hold in South Dakota in 1908 when three pairs brought from Oregon were released near Redfield, SD, the self-proclaimed "Pheasant Capital of the World". Today, pheasants can be found from California to Maine and from Texas to southern Canada. In 2007, South Dakota led the way in estimated harvested birds with over 2 million, a suitable proxy for bird abundance. Rounding out the top six states were North Dakota $(907,000)$, Kansas $(887,000)$, Minnesota $(655,000)$, Iowa $(632,000)$, and Nebraska $(437,000)$ (Pheasants Forever 2008).

Thousands of hotels, motels, rented houses, and spare bedrooms are booked solid each year in anticipation of the opening weekend of pheasant hunting in some of the larger cities and towns of eastern South Dakota, especially in areas frequented by both resident and non-resident pheasant hunters. (Figure 3). The differing patterns of where resident and non-resident hunters hunt is mostly a reflection of South Dakota's population distribution. Many of South Dakota's 781,000 residents do not stray far from home and hunt along the Interstate 29 corridor. While non-residents also hunt these areas, most frequent the east-central towns of Chamberlain, Pierre, Aberdeen, Redfield, Presho, and others. Pierre and Aberdeen have airports that service larger hubs such Minneapolis and also have adequate hotel space and restaurants to serve the needs of the non-residents. Additionally, these areas are 
also home to many of the privately run pheasant hunting lodges that are used mostly by the nonresident hunters.

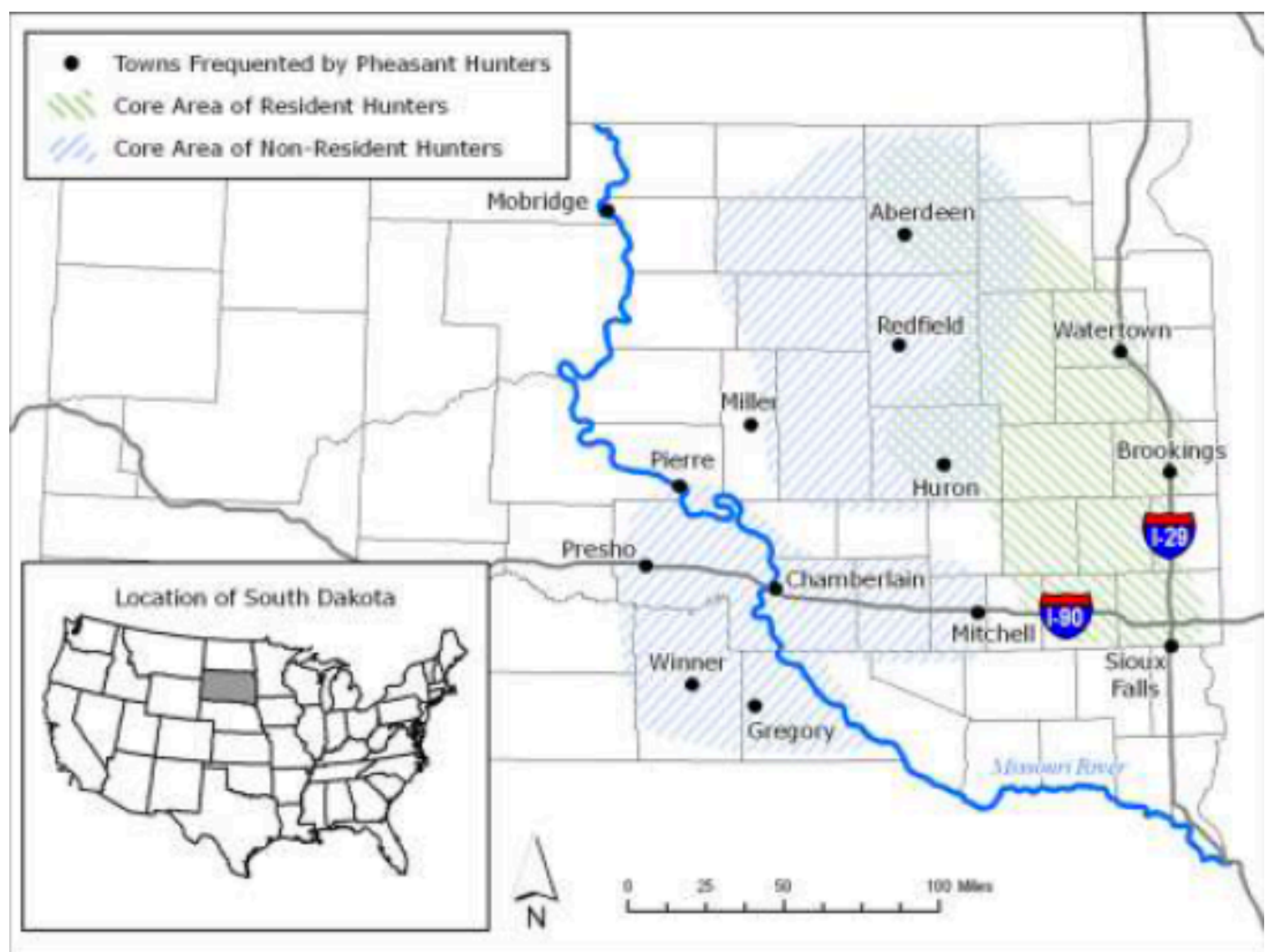

Figure 3: South Dakotan towns and areas frequented by pheasant hunters. Stippling and hash marks indicate where most residents and non-residents hunted pheasants in South Dakota in 2006. The data are based on a survey I sent to 1,000 resident and 1,000 non-resident hunters during the spring of 2007.

Many of these towns have erected shrines to celebrate this coveted bird. The world's largest pheasant (Figure 4) can be found perched atop the Dakota Inn Hotel in Huron, South Dakota. The world's second largest pheasant (Figure 5) is found in the town of Gregory, which at the beginning of the current pheasant boom in 1992, Fortune Magazine declared "The Ground Zero of Pheasantdom" (Farnham 1992). 


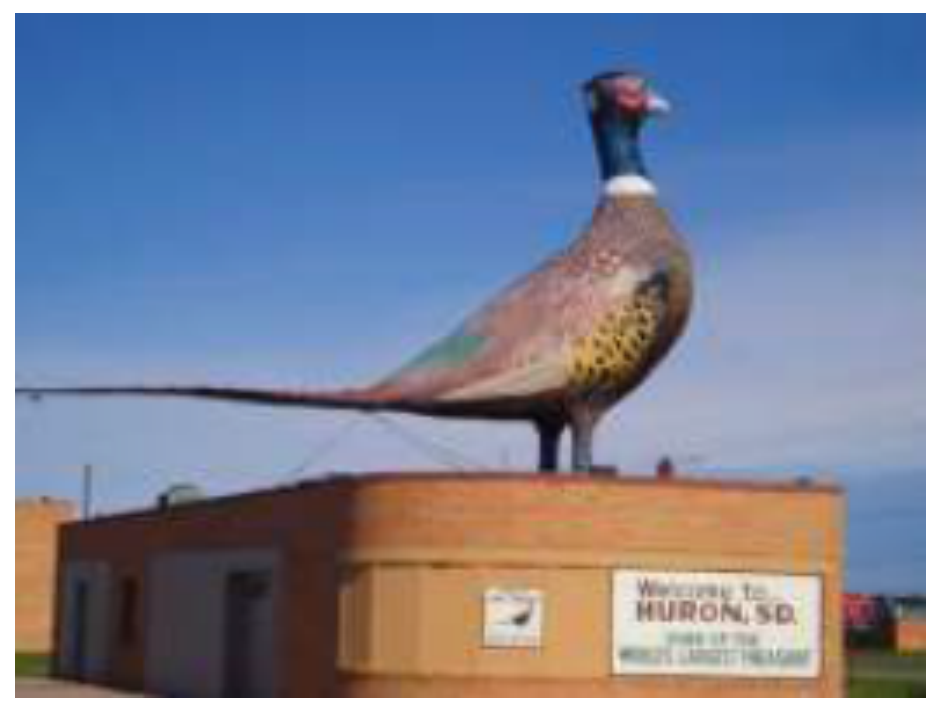

Figure 4: Statue of pheasant in Huron.

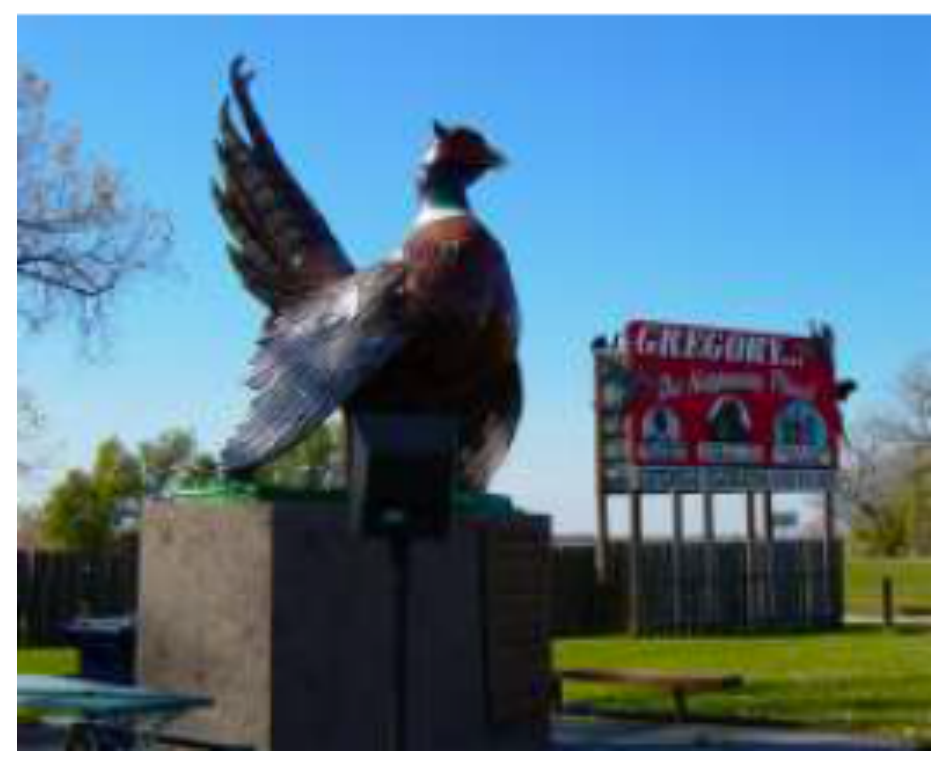

Figure 5: Gregory's giant pheasant.

References to pheasants abound in South Dakota: giant birds on hotels, billboards along highways, advertisements in outdoor magazines, and even school mascots like the fighting pheasant of Parker High (Figure 6). One image, however, epitomizes the importance of the pheasant to South Dakota more than any other. When residents were asked to vote among five designs for South Dakota's commemorative quarter, the one chosen not only portrayed Mt. Rushmore, an American icon, but also an Asian native - the ring-necked pheasant (Figure 7). 


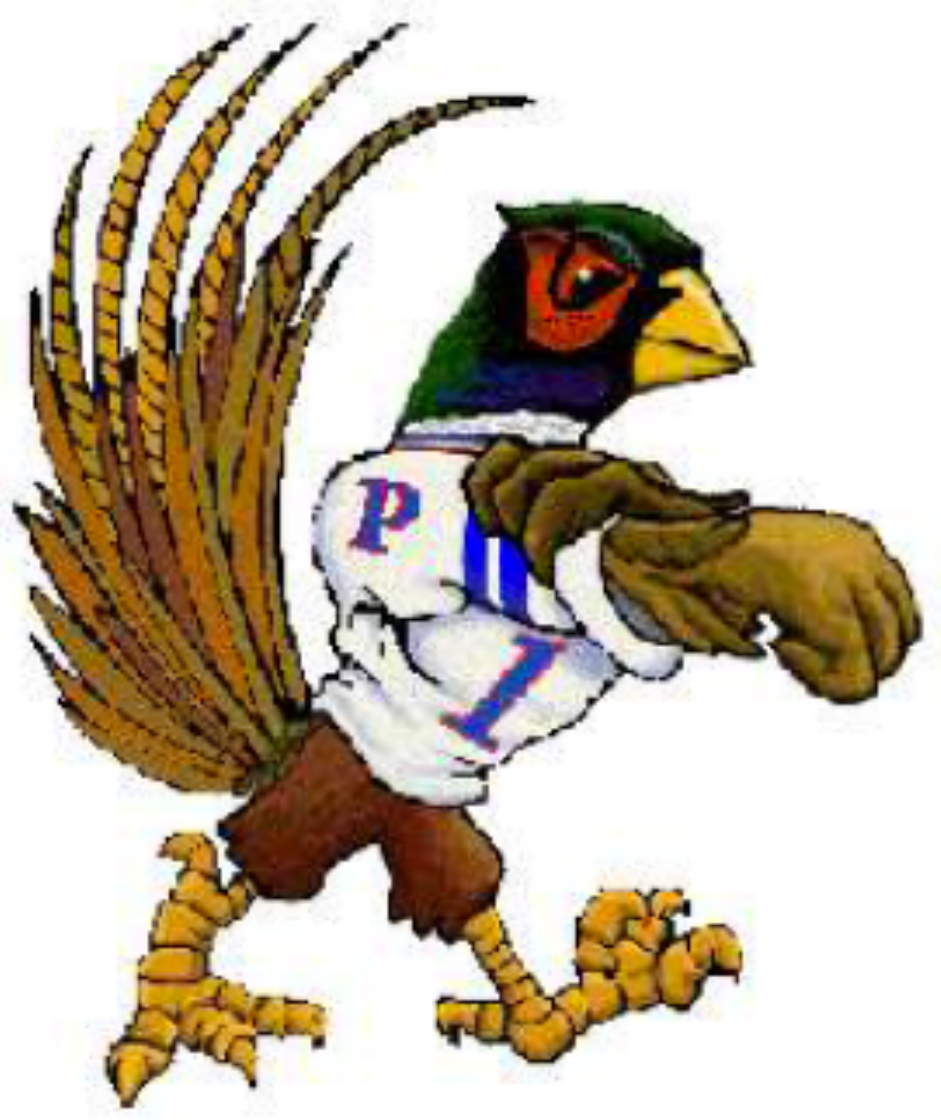

Figure 6: Parker High School Fighting Pheasant. Source: Parker High School, http://mb124.k12.sd.us/ 


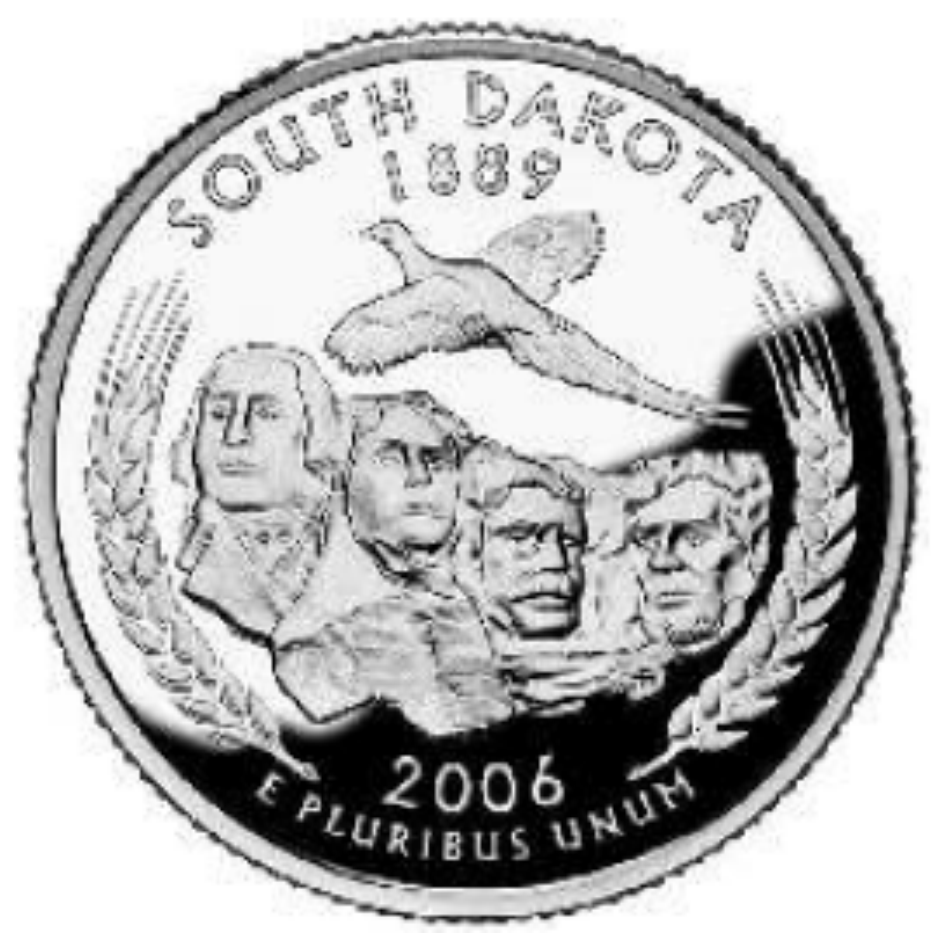

Figure 7: The 2006 State Quarter of South Dakota. Source: U.S. Mint, www.usmint.gov.

Boom and bust cycles in pheasant populations have been common in South Dakota. During the mid-1900s good weather and abundant habitat brought populations to record highs (Trautman 1982). Early cropland retirement programs of the 1930s and 1950s/60s have also influenced population cycles (Edwards 1994). These programs, coupled with favorable weather, were responsible for record numbers of pheasants in the 1940s years that may never be eclipsed. More recently, the impact of the Conservation Reserve Program (CRP), which also coincided with milder weather and habitat-friendly land use practices, has created another boom in pheasant population and hunting in South Dakota (Ryan, Burger, Kurzejeski 1998). Historically, when populations suffered severe declines, it was likely a response to changes in both land use and weather (Labisky 1976; Trautman 1982).

The relationships and feedbacks among pheasants, land use, policy, and climate/weather in South Dakota are the focus of this article. I begin by looking at what makes South Dakota special when it comes to pheasants and pheasant hunting. Then, I examine three periods of time, each corresponding with a combination of both human and natural driving forces that together helped to change land use and land cover, along with pheasant habitat, populations, and hunting. Finally, I look at current issues surrounding the CRP and compare past changes in government land retirement programs to what is happening today. 


\section{Weather and Habitat}

Pheasant numbers fluctuate in the extremely dynamic continental climate of South Dakota (Winter and Rosenberry 1998). Precipitation deficits coupled with environmentally unstable land use put South Dakota on the northern edge of the 1930s Dust Bowl. Conversely, precipitation surpluses in the 1990s caused extreme flooding in eastern South Dakota, creating Lake Thompson, a former wetland complex that is today the state's largest lake (Winter and Rosenberry 1998). Recent increases in temperature and growing degree days (Graesser 2008) have allowed crops such as corn to become viable and profitable options for farmers in northeastern South Dakota. Long-term climate changes affect and often drive land use change, and thus strongly influence the size of the state's overall pheasant population. Short-term, annual variations such as severe winters or cool, wet springs are also important and can cause dramatic local decreases in pheasant numbers (Trautman 1982).

What really sets South Dakota apart is what wildlife biologists term the 3-H's: Habitat, Habitat, and Habitat (South Dakota Game, Fish, and Parks 2008c). Historically, eastern South Dakota has had a near perfect blend of row crops, small grains, fallow land, pasturelands, grasslands and abandoned farmland (Figure 8). Climate and soil dictated what grew well in this region, and what did made prime conditions for pheasant nesting, feeding, and cover from predators and weather. Periodic changes in landowner decisions based on agricultural markets and policy brought about habitat changes and created boom and bust cycles in pheasant populations.

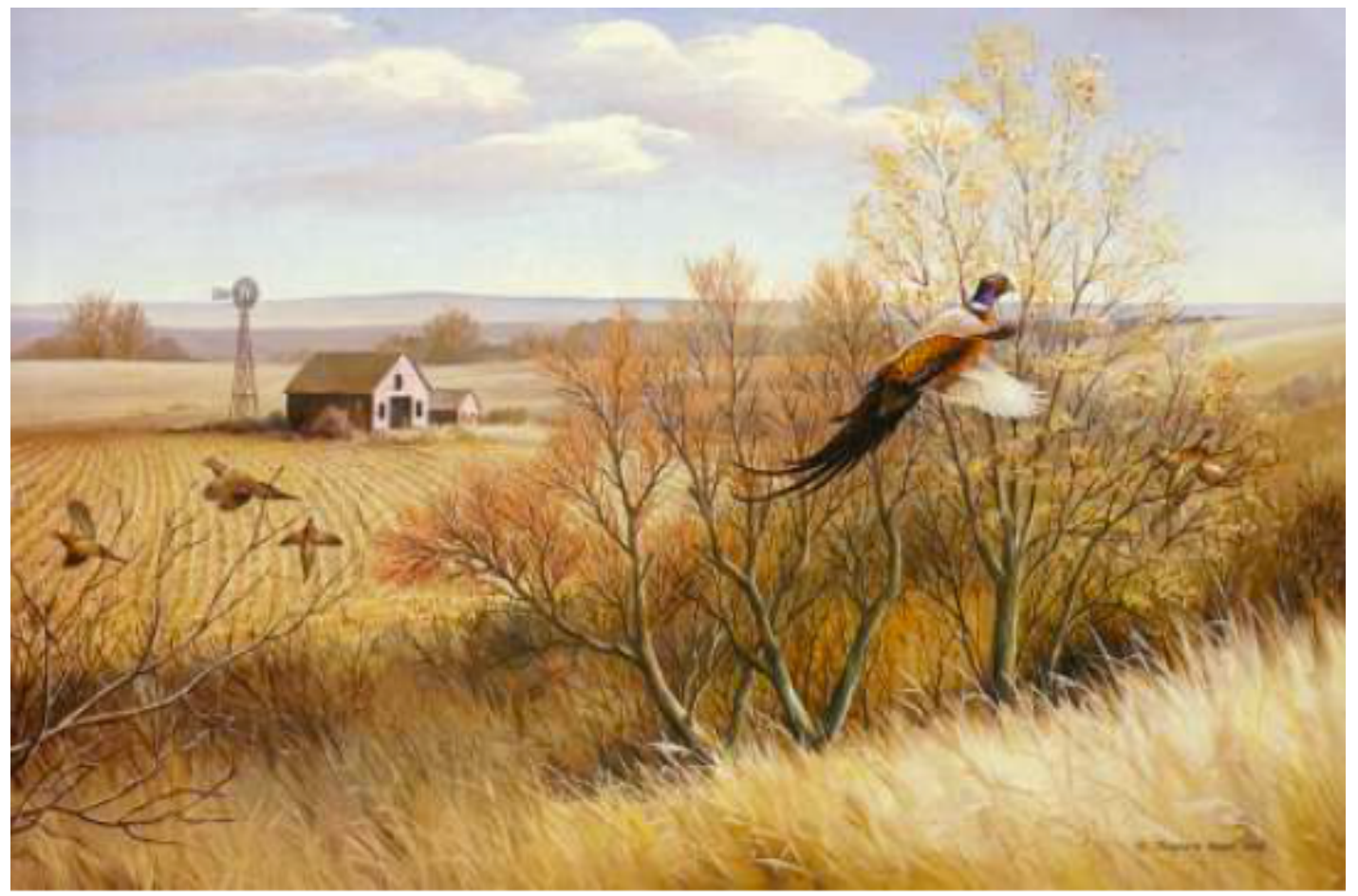


Figure 8: It is next to impossible for a camera to capture the true diversity of the eastern South Dakota landscape. This painting by Maynard Reese entitled "Weedy Draw" comes close, capturing the elements of row crops, grasslands, idle acres, and an abandoned farm site. Source: www.maynardreesegallery.com. Used with permission from the Maynard Reese Gallery, Des Moines, Iowa.

Agriculturally, this region is close to the western fringe of the Corn Belt, that stretches from Illinois westward through Iowa and Minnesota. Eastern South Dakota has a more diversified crop composition than the core Corn Belt states, where agricultural land cover is predominantly corn or soybeans. This diversity is reflected in a comparison between one of Minnesota's best pheasant counties, Jackson, with one of South Dakota's best, Gregory, 250 miles farther west (Figure 9). Virtually all agricultural lands in Jackson County are planted to corn or soybeans, whereas Gregory County has a diversified mix of corn, soybeans, forage, and small grains. Landscape diversity is key to pheasant survival, both for food and cover (Vandel III and under 1981). Even idle, unmowed patches of grasslands around abandoned farmsteads, field corners, and section lines are extremely beneficial to pheasants.
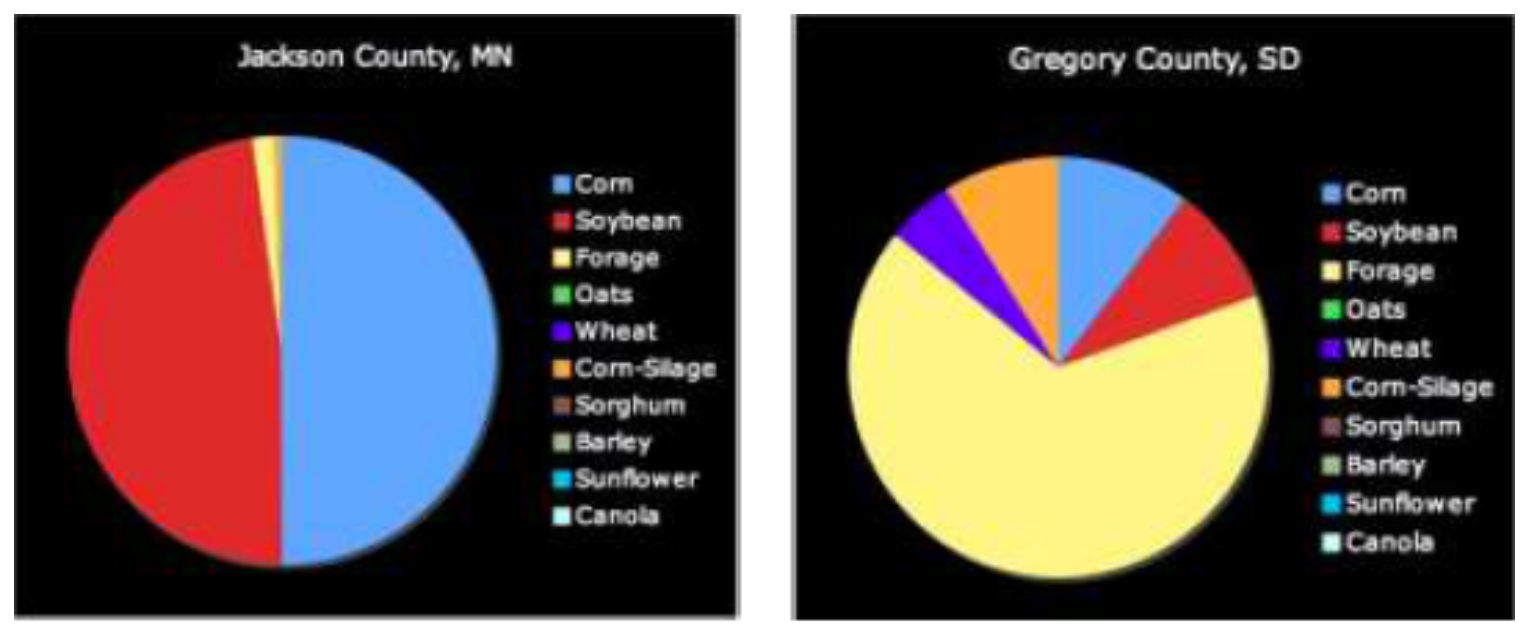

Figure 9: Agricultural land use patterns in Jackson County, MN and Gregory County, SD. Source: USDA 2008b and 2008c.

\section{Public and Private Hunting Lands}

A crucial component of the pheasant-friendly land use mosaic is South Dakota's public land. Ten percent of the state's land area is in some type of public land program (Coughlin 2008). Much of it lies in the western part of the state where pheasants are less abundant (for example, the large tracts of U.S. Forest Service lands in the Black Hills and the vast expanses of BLM lands), but significant public land is found in eastern South Dakota pheasant country as well. 
The acquisition of these lands can be greatly attributed to federal and state agencies such as the U.S. Fish and Wildlife Service and the South Dakota Department of Game, Fish, and Parks, which created programs to help fund the purchasing of lands suitable for wildlife. The federal Duck Stamp Act of 1935 authorized acquisitions of wetlands as Waterfowl Production Areas (WPA). Nearly 95 percent of these are located in the Dakotas, Montana, and Minnesota (U.S. Fish and Wildlife Service 2008e). To date, over 150,000 acres of wetlands and grasslands have been purchased in South Dakota using money from the sale of federal duck stamps (Coughlin 2008). While the purpose of these lands initially was to help waterfowl populations, wildlife in general, including pheasants, benefitted from these lands acquired and set aside by conservation minded organizations and landowners (Figure 10).

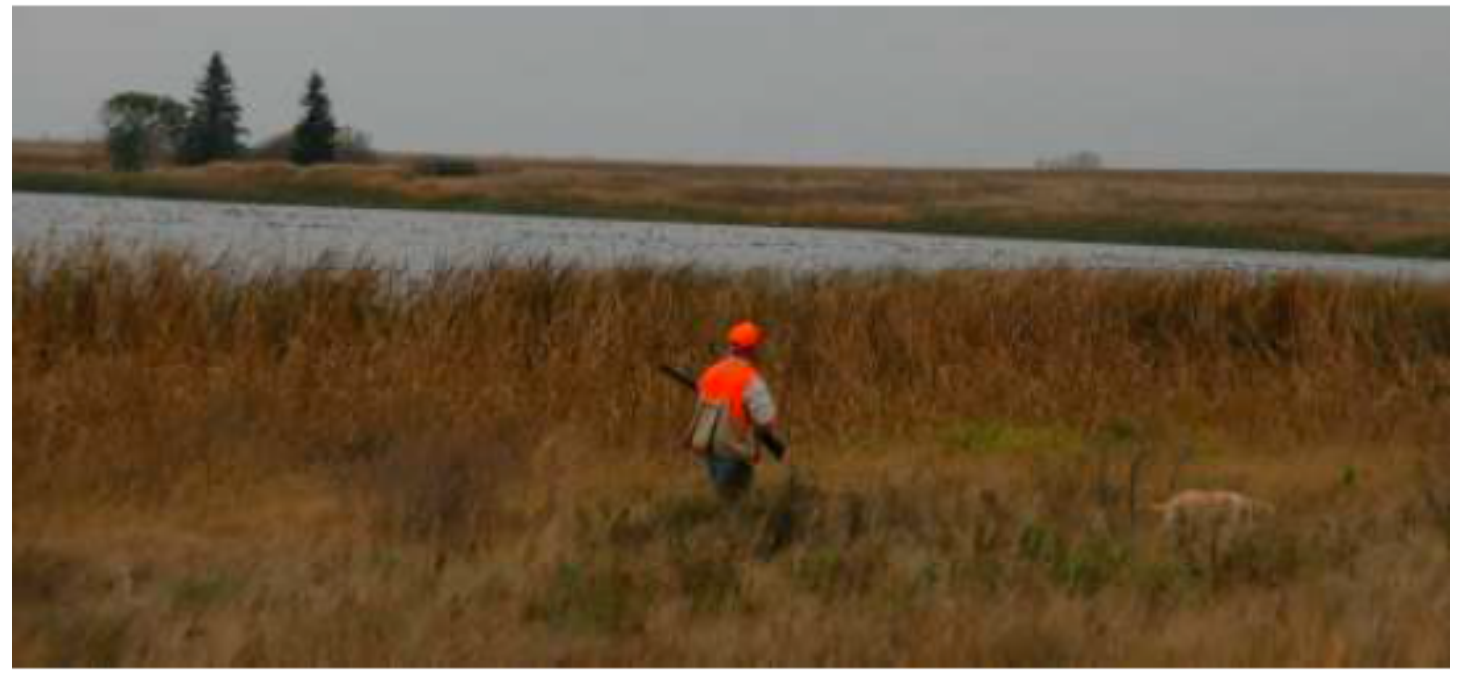

Figure 10: An example of a federally owned Waterfowl Production Area. Photo by Wade Harkema.

In addition to the federally owned lands, the state also has set aside conservation land. Game Production Areas (GPAs) are managed for the production and maintenance of all wildlife species, although emphasis varies from site to site (Figure 11). South Dakota has 696 GPAs totaling more than 250,000 acres. Money to purchase these lands comes from state hunting license fees (Smith 2008). The land cover of these varies, but is usually a mix of grasslands, wetlands, and in some cases plots of food crops such as corn, sorghum, or some other field crop. 


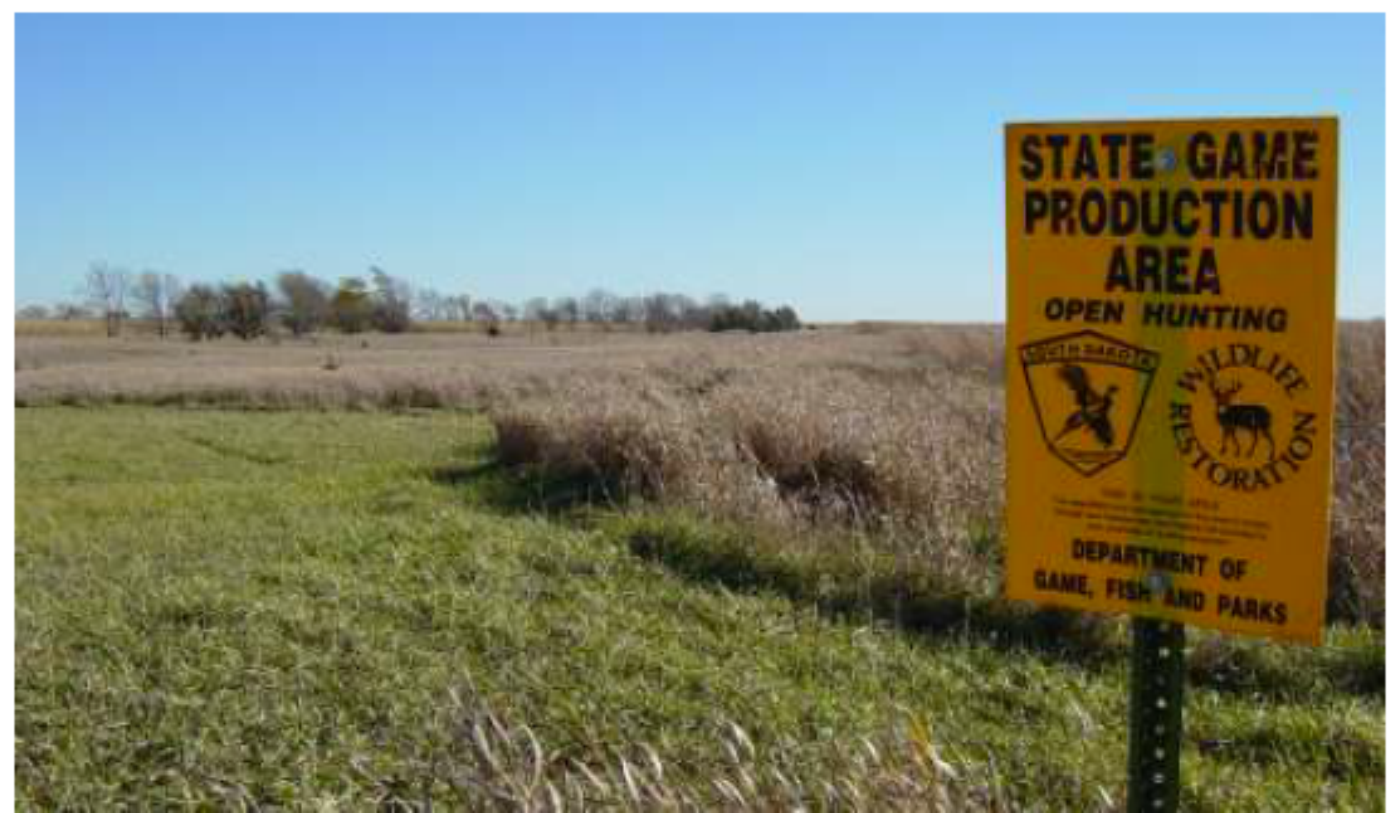

Figure 11: The distinctive sign (at least to hunters) of a state-owned Game Production Area.

Walk-In Areas (WIA) are another state program (Figure 12). These lands are rented by the state from landowners at a rate of $\$ 1$ per acre and an additional $\$ 5$ per acre for land that is in a permanent cover beneficial for wildlife, such as wetlands or native grasses (Smith 2008). The quality of habitat in WIA varies greatly, and it is rarely of the quality that one finds in WPAs or GPAs. For example, two farmers may enroll two 40 -acre plots in a WIA contract. One of them may be a 40 -acre grassland that can be hunted in its entirety, whereas the second farmer may have enrolled a 40 -acre plot with a two-acre wetland surrounded by 38 acres of soybean stubble. It is still considered a 40 acre WIA, but the only beneficial habitat is the two-acre wetland. 


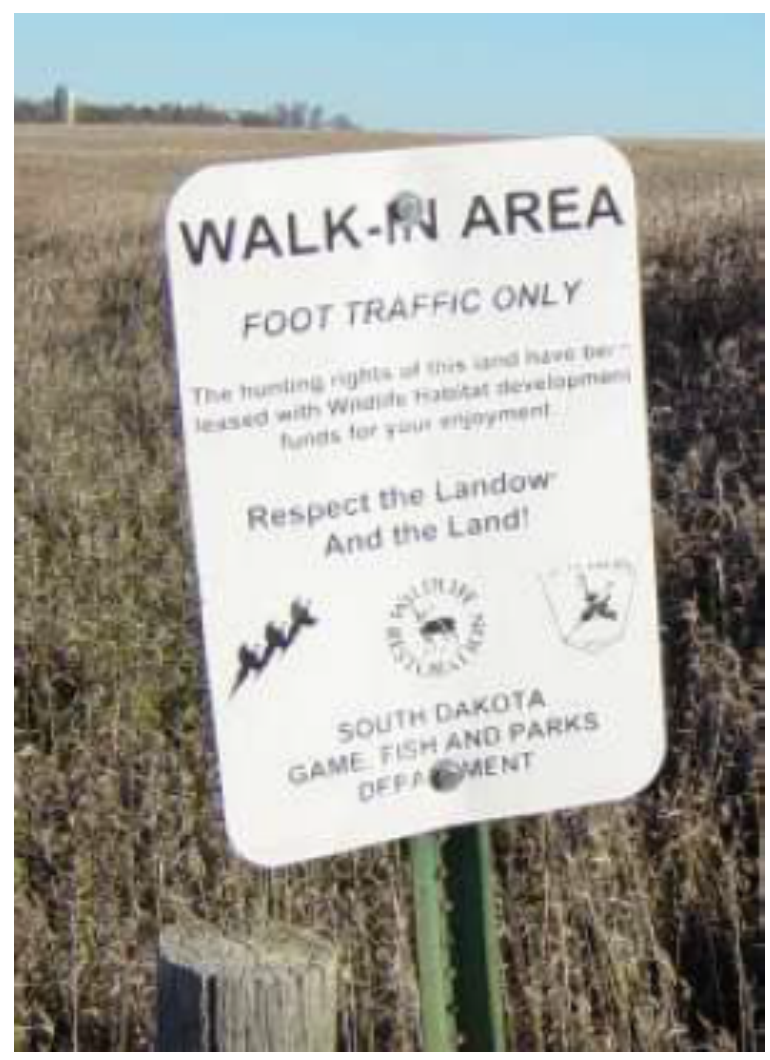

Figure 12. An example of a state leased Walk-In Area.

The last and most interesting type of public lands available for hunting is the public right-of-way (ROW). ROWs range from paved roads to unkempt minimum maintenance roads found along the old Public Land Survey System section lines. In South Dakota it is legal to walk along these and, if one stays within the legally defined 66-foot ROW, to hunt pheasants on them. It is also legal to hunt while driving a vehicle on any public ROW except state and federal highways in what is known as "road hunting." When a pheasant is spotted or heard scurrying into the ditch, hunters park their vehicle, get out, and shoot the bird if it takes flight (Figure 13)[2]. Although many purists find this method unappealing and lazy, it is a big draw to many as both public and private lands become more crowded with hunters. 


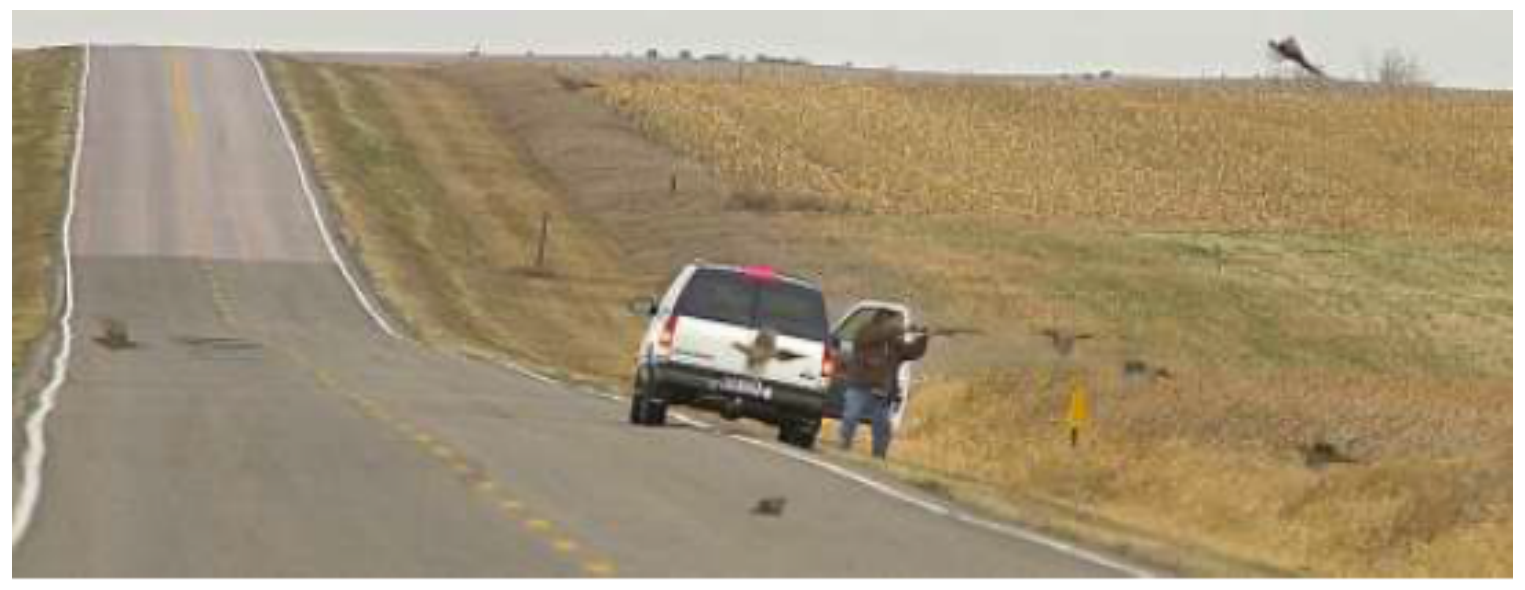

Figures 13: Road hunting in South Dakota. Photo (by Laura Neel) used with permission of Sioux Falls Argus Leader.

Not surprisingly, road hunting is a contested practice, especially when land adjacent to the ROW is part of a private hunting business. The South Dakota Supreme Court has heard cases in recent years from landowners wanting to ban road hunting because birds they raised and released for their paying hunters wandered off private property and into the public ROW, becoming fair game for all hunters (Berg 2006). The question arose, whose bird was it? The private landowner may have purchased the bird as a chick and later released it, so he feels entitled to it and the money it is worth, but someone road hunting has no way of knowing the origins of the bird (Figure 14). Another issue involved with this debate is whether or not a hunter can shoot a bird flying over private property if the hunter is within the 66foot ROW. If the bird takes flight from the ROW, it is legal. If the bird takes flight from private land, it is not. Each county has only one conservation officer, so many "border" issues such as these are often impossible to enforce, which can lead to greater controversy. The courts have always ruled in favor of road hunting, but quarrels over private versus public land accessibility are far from over (Shouse 2004b). 

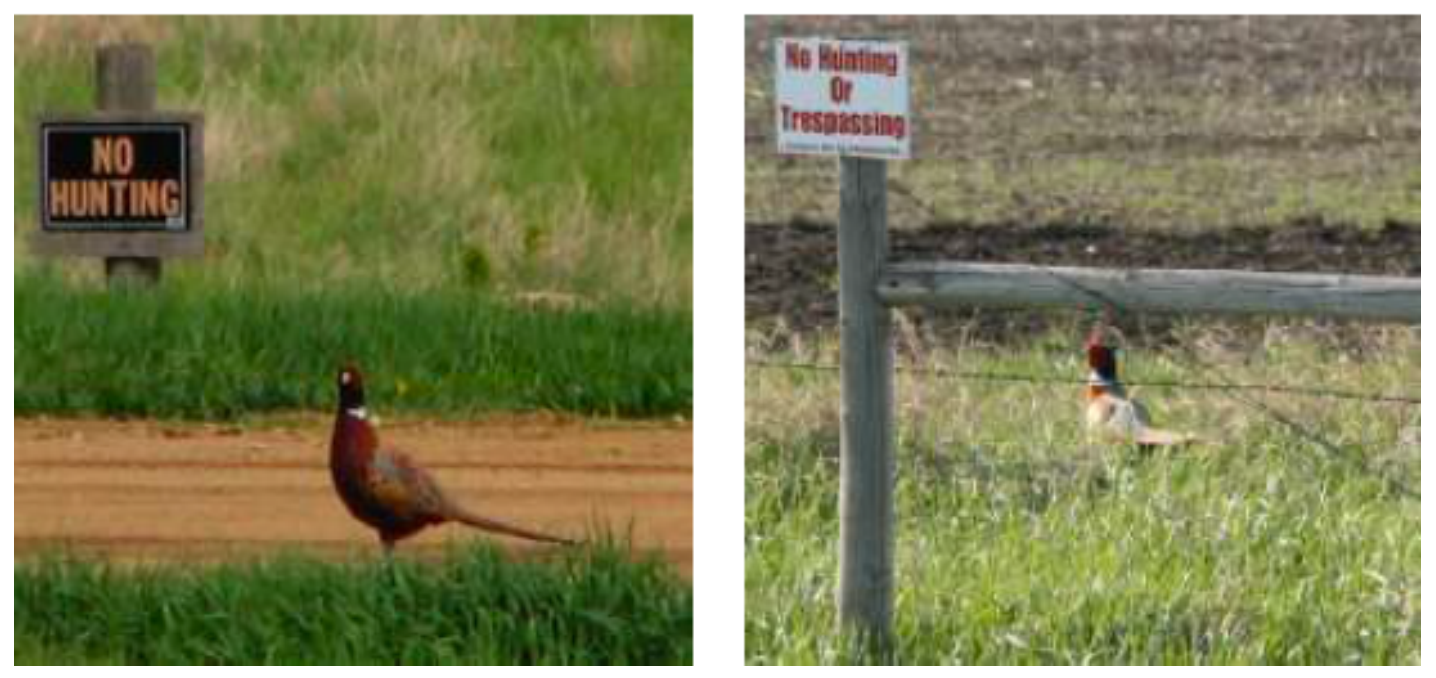

Figure 14: Pheasants found at the edge of the private/public property boundaries have sparked debate over the ownership of the birds. (Anecdotal evidence shows some pheasants, especially those that are seasoned veterans of past hunts, have learned to read, helping them live to see another day!) Photos by Wade Harkema.

Private land is also available for hunting. Some landowners have enrolled their land in "preserves" (South Dakota Game, Fish, and Parks 2008d), paying fees to the state and releasing pen-raised pheasants to help replace the birds harvested, whether they were pen-raised or wild. The establishment of a preserve entitles these operations to a longer hunting season and a higher bag limit. Instead of an autumn season lasting three and a half months, preserves can be hunted from September to March.

Pheasant farms, businesses set up by landowners or businessmen that cater to hunters, are another way private land becomes available (Figure 15). They are actually more common than preserves (Woster 1999). These establishments may consist of only a spare bedroom in someone's house who allows you to hunt their land, or be an all-inclusive resort, offering clients dining, lodging, transportation, game cleaning, and equipment (Figure 15). These outfitters tend to appeal mostly to non-resident hunters, or those who have the financial means to spend hundreds or thousands of dollars for five days of vacation pheasant hunting. 


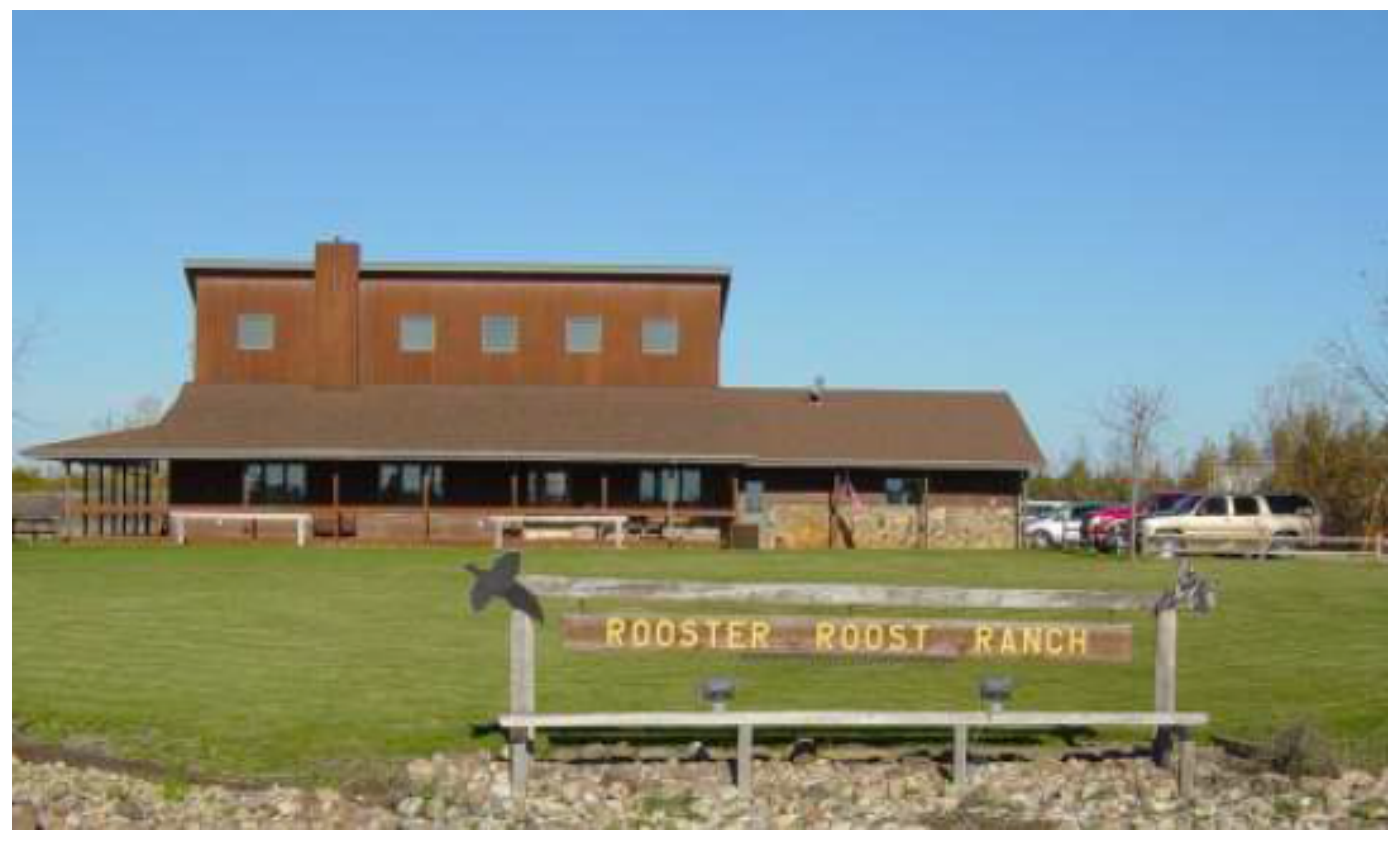

Figure 15: The Rooster Roost Ranch, and example of a private pheasant "lodge", just south of Mitchell, South Dakota.

The majority of private-land hunters, however, simply frequent the croplands, wetlands, pastures, or grasslands owned and operated by rural residents. Hunters from around the world make the annual pilgrimage each year. Some access the land of family or friends, and some may be private landowners themselves. In the past it was not uncommon to drive up to someone's residence, ask permission for access to their land, and enjoy a full day of hunting. As pheasant hunting becomes more profitable for landowners who charge hundreds or even thousands of dollars per person for private land access less free access land than in the past is available for the ever-increasing number of hunters. Today, with more private landowners charging hunters for access, more complaints of hunter trespass, and more quarrels between landowners and hunters over access rights, residents who have hunted their adjacent neighbor's land for years are being turned away (Figure 16); so many have purchased their own land just for pheasant hunting (Woster 2006). 


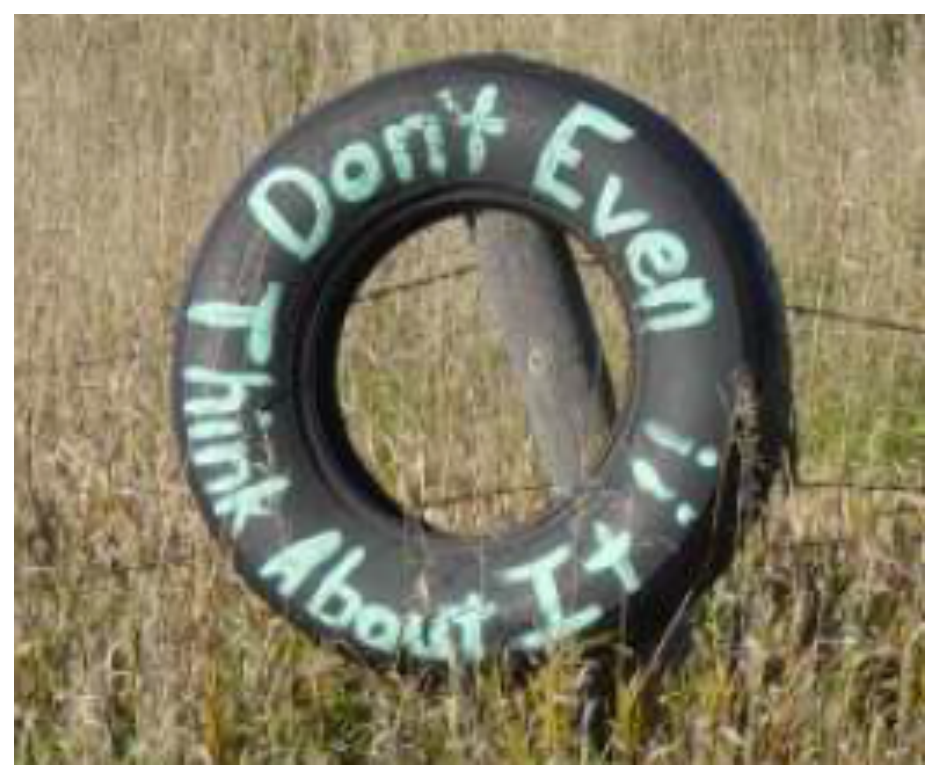

Figure 16: Old tires often have a second life as signs warning hunters that unless they have permission to hunt on this land, their presence on it is not welcome.

Over the past seven years, the percentage of people purchasing land for hunting or recreation in eastern South Dakota has increased from 16 percent to 23 percent (Janssen, Pflueger, and Ahrendt 2007). In 2003 alone, thirty-four hunters bought 9,848 acres, or more than fifteen square miles of land (Shouse 2004a). As the population of rural South Dakota continues to decline, farmstead auctions are commonly attended not only by local farmers bidding on farmland, but also by people on cell phones, calling outbids from as far away as Florida in hopes of securing their own piece of hunting land on the South Dakota countryside (Shouse 2004a).

\section{Booms and Busts}

Since 1920, pheasant populations have experienced four boom periods and three bust periods (Figure 17). These booms and busts were driven by changes in policy, land use, and climate /weather. The first boom period began in the "Dirty Thirties" (1930-36). Crop failure caused by long-term drought and a major economic depression led to "slip-shod farming practices" (Trautman 1982, 59). With bank failures and landowner bankruptcy, farmland was abandoned and it reverted to weeds and grasses. At the same time, the first major government land retirement program was enacted in 1936 the Agricultural Conservation Program (ACP). In the new landscape of abandoned farmlands and increased expanses of grassland, pheasant numbers quickly reached 12 million. 


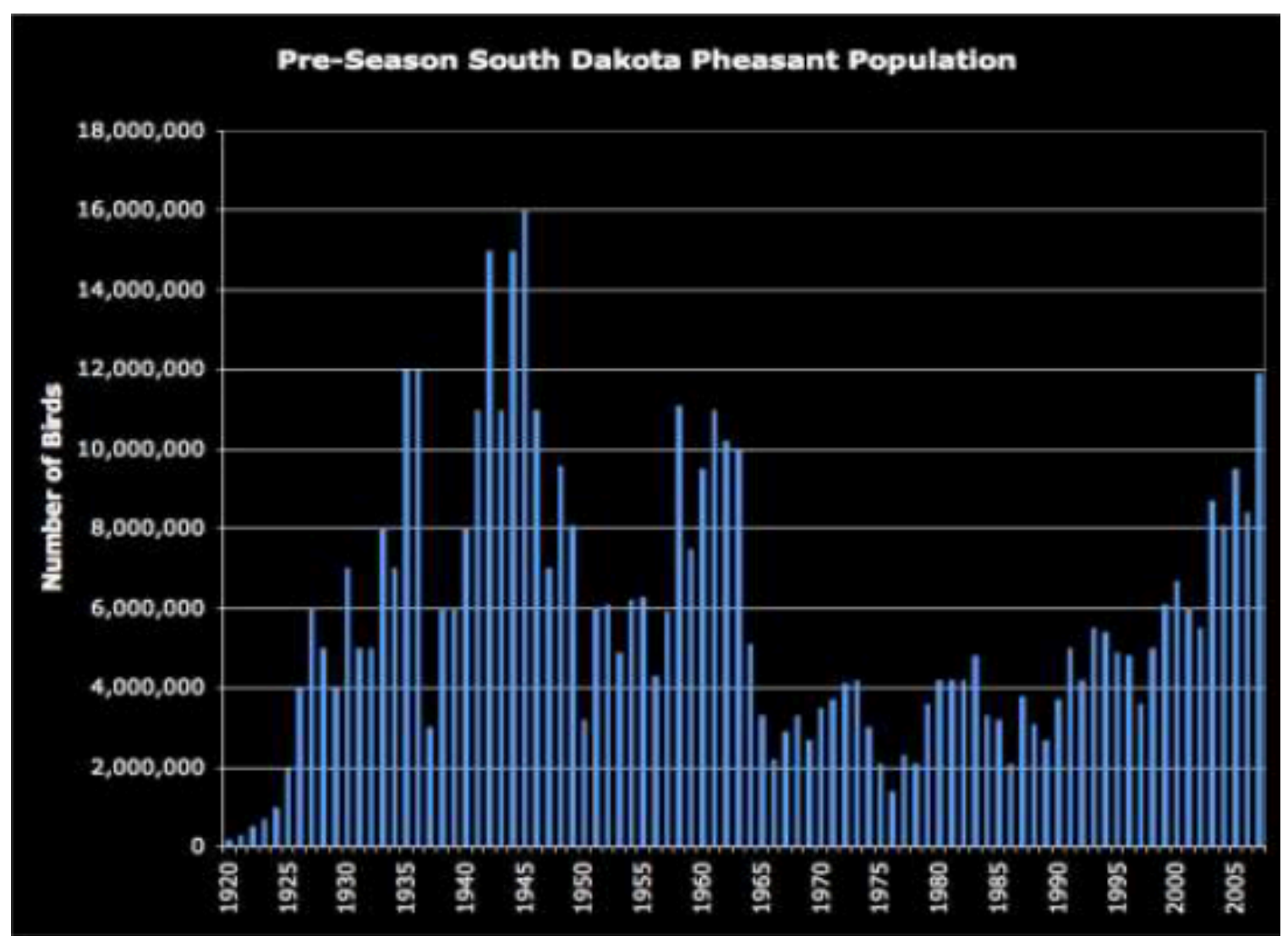

Figure 17: The booms and busts of the South Dakota pheasant population: 19202007. Source: South Dakota Game, Fish, and Parks 2008b.

A short-lived bust followed this boom. Climate conditions ameliorated from the Dust Bowl years, and farmers were again able to till more acres. Pheasant habitat w as lost. Pressures on the pheasant population were compounded by the most severe period of starvation among the birds in history. Eighty percent of the population was lost during the winter of 1937, when more than 70 inches of snow fell on eastern South Dakota, accompanied by prolonged sub-zero temperatures (Trautman $1982,63)$. Nonetheless, even with the loss of natural habitat, the diversified farming of this period helped populations recover quickly; and they continued to increase into the second boom period, which occurred during the years of World War II.

During the war, tractor fuel was rationed and farm laborers were scarce (Trautman 1982, 59). Agriculture declined, creating large acreages of partially used croplands and expanding grasslands both prime habitat for pheasants. The climate of those years was also pheasant friendly. Above normal rainfall filled the numerous "prairie potholes" of eastern South Dakota and supported sturdy and dense stands of vegetation that became much needed protective winter cover for pheasants. Populations reached an estimated 16 million birds in 1946, the highest ever recorded and most likely the highest that will ever be seen (South Dakota Game, Fish, and Parks 2008b). 
The second bust period began when World War II ended. Soldiers came home to their farms and began working the land again, removing vital nesting and winter habitat. Exacerbating this second decline in habitat were changes in the weather: warmer than normal spring temperatures spoiled hatches in 1946, another severe winter struck in 1947-48, and a second abnormal spring hatch occurred in 1950 (Trautman 1982). These factors, as well as increased bag limits, led to another major decline.[ ] $]$

Pheasant population dynamics changed dramatically during the 1950s. Agriculture became more intensive and less diversified, with the result that populations were much slower to rebound after catastrophic losses. Severe weather events such as blizzards had a much more lasting impacts on pheasant populations. In earlier bust periods that had followed habitat losses or severe weather events, populations had recovered relatively quickly, normally in five to ten years.

The third boom period began in 1956, lasted for about eight years, and corresponded to the establishment of the precursor of today's CRP, the Soil Bank (Edwards 1994). Agricultural lands were taken out of production and seeded into perennial legumes and grasses. Pheasant populations increased to an estimated 11 million birds.

The Soil Bank boom was short-lived. Emergency haying programs were authorized by the government in the early 1960s to offset forage losses caused by drought (Trautman 1982). Deep snows in the winter of 1964-65 and cold spring temperatures in 1965 caused hatch success to decline significantly. In 1966 a severe blizzard struck eastern South Dakota. Wildlife biologists estimated an 86 percent mortality rate for pheasants (Trautman 1982). Luckily, because of some remaining cropland diversity and stands of cattails in wetlands that had not yet been drained and farmed, some pheasants did find winter cover.

This third bust period lasted from the mid-1960s to the mid-1980s. Decreases in the pheasant population were linked to the aforementioned weather impacts, but also to changes in agricultural markets and policy (Erickson and Wiebe 1973). Following the years of land enrollment in Soil Bank, which at its peak removed 1.8 million acres in South Dakota (Edwards 1994), the U.S. government turned its agricultural policy from conservation to production as new markets for surplus agricultural commodities opened in the USSR and China (Hart 1991). With increased corn prices, land in conservation acres, along with pastureland and other idle acres, was converted back to production-based uses. The result was the loss of suitable habitat both for nesting and winter cover, to the detriment of pheasants.

A trend from diversified to monoculture (fence row to fence row) farming also removed pheasant-friendly habitat. In 1975, another severe blizzard struck, taking away any gains that pheasants had made in their population recovery. By 1976, numbers had dropped to record lows, lows not seen since the introduction of the bird in the early 1900s (Trautman 1982). 
The last boom period began in 1986 with the start of the CRP and efforts by wildlife conservation organizations such as Pheasants Forever (established in 1982) to help manage lands specifically for pheasants. The CRP was created in 1985 as a federal program to retire highly erodible and environmentally sensitive cropland and pasture, and is generally set aside in ten to fifteen year contracts (Leathers and Harrington 2000). Initially designed as a supply control program, in more recent years it has evolved into a land retirement program designed to meet many environmental objectives (Klein et al. 2008). Currently, South Dakota has 1.3 million acres of land in CRP, or 6.5 percent of the state's cropland acres. As under the Soil Bank program, a positive correlation is seen between the amount of acres in CRP and pheasant numbers (Eggebo et al. 2003). The only noticeable mini-bust periods occurred during two severe winters in 1997 and again in 2001. Just as in the years of the Soil Bank, when secondary winter cover was available on idle lands, pheasants of the 1990s had grasslands for refuge from severe winter weather. Contemporary farming practices such as no-till left wheat and corn stubble on the surface which provided a beneficial food resource and, by trapping blowing snow, limited snow accumulations in the grasslands and wetlands that pheasants used for cover (Figure 18).

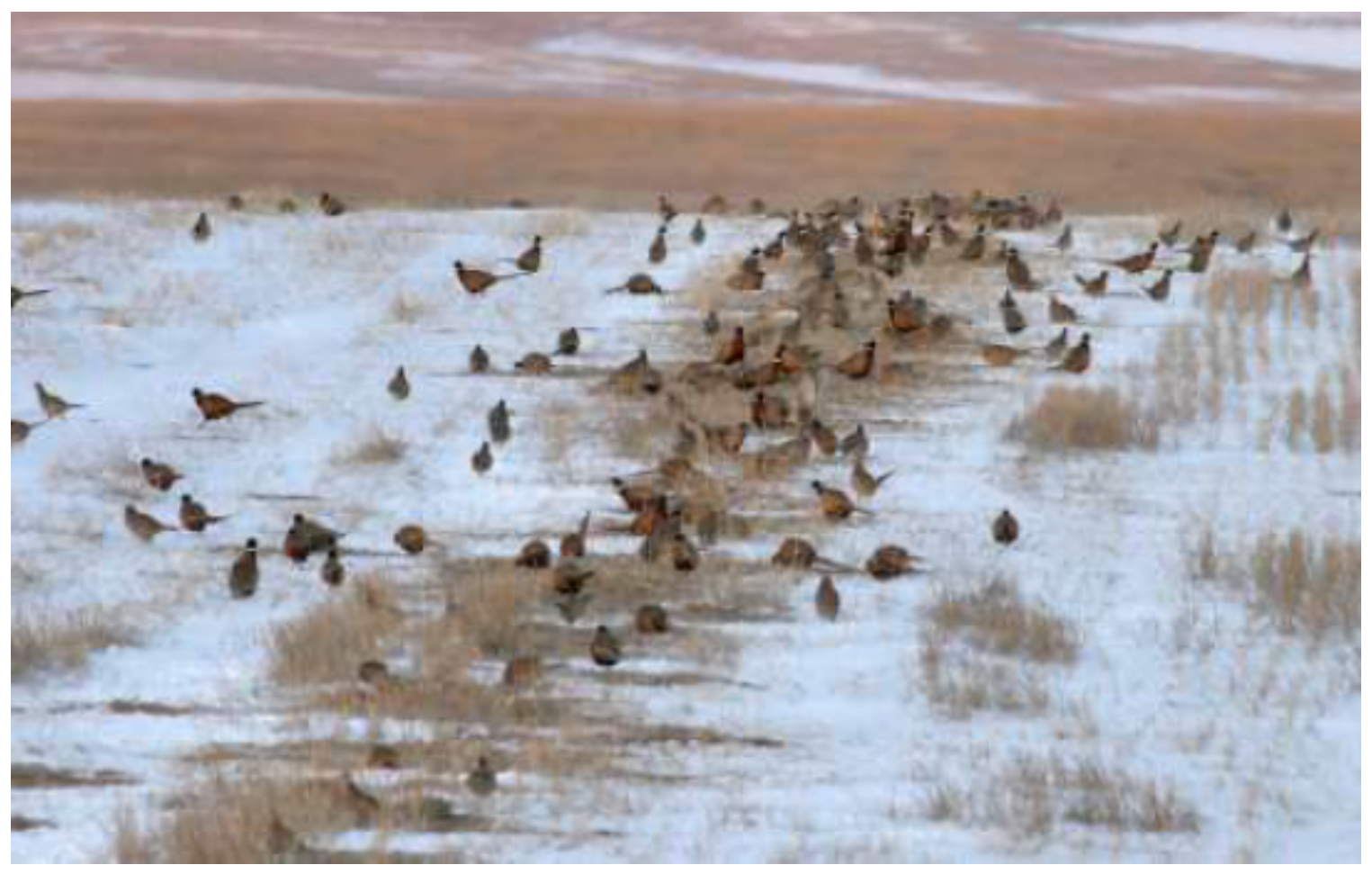

Figure 18: Pheasants in wheat stubble near Presho, SD. Photo by Terry Sohl.

Wildlife conservation innovations directly aimed at helping pheasants (such as notill), along with the CRP, saved countless birds' lives (Ristau 2007). In addition, many landowners had planted rows of trees that trapped blowing snow in the windward rows, leaving leeward rows almost devoid of snow (Woster 2001b). 
Rows of trees planted in areas near grasslands and food sources are an example of a local scale land use change that helps pheasants survive the sometimes brutal winter weather of the upper-Midwest (Ristau 2007)

\section{CRP and the Future}

Today, the big question is what will happen now that existing CRP contracts are set to expire (Figure 19) and no new general signups are being offered. General signups are those that enroll large tracts of land into 1015 year retirement contracts. These large "general" enrollments (as opposed to "continuous" enrollments that only enroll small strips of land or buffers) have the biggest impact on pheasant populations as they do the most to protect the pheasants from predators and the weather. The top five pheasant hunting states in the Midwest stand to lose hundreds of thousands of acres of prime pheasant habitat, mostly due to the loss of lands taken out of the "general" enrollments.

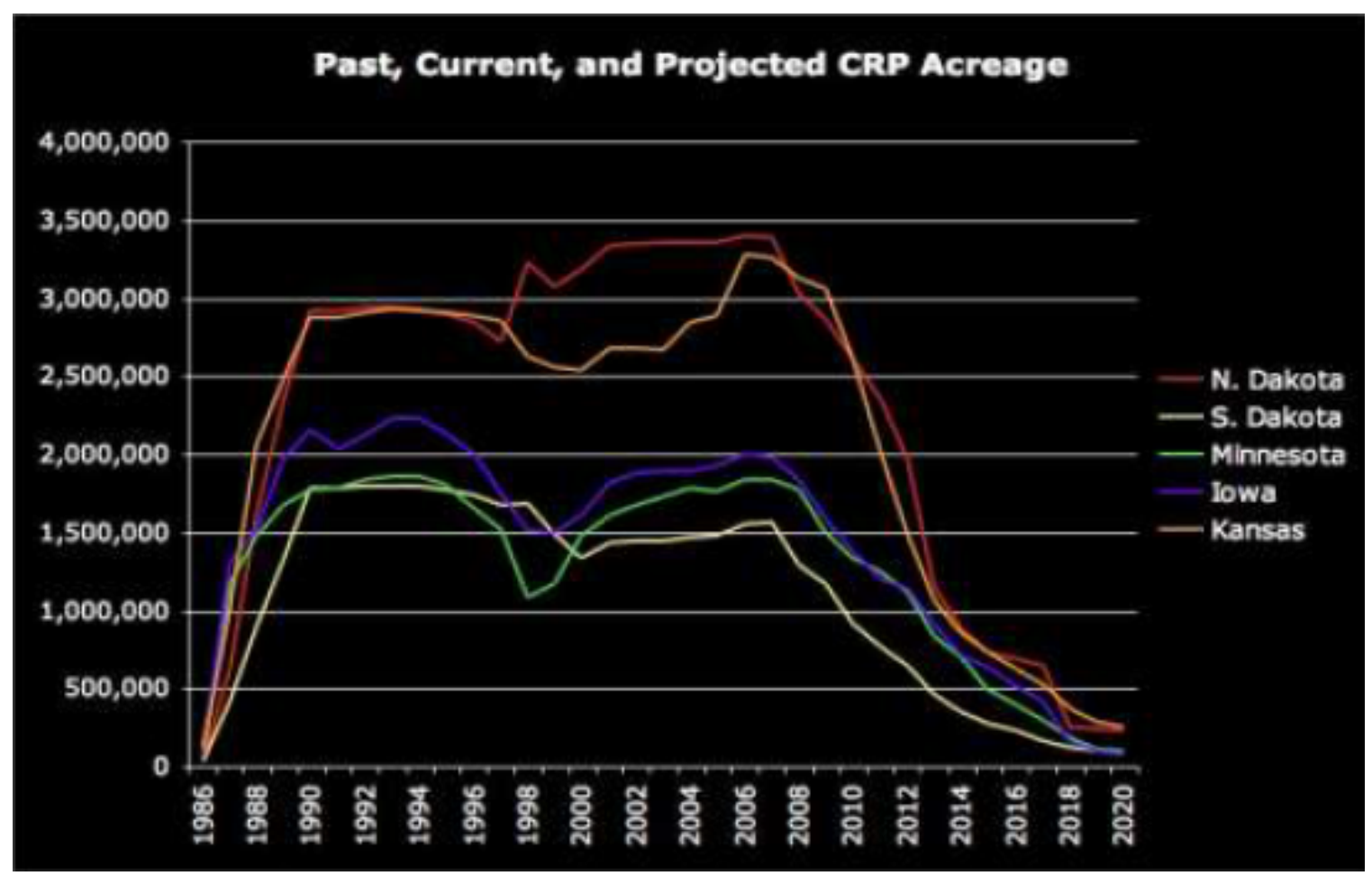

Figure 19: Expiring CRP acres in five Midwest states. No new general signup is scheduled to be offered. Source: USDA, 2008a.

In a study recently completed for the USDA (Nielson et al. 2007), results showed that with every 4 percent increase in large tract CRP acreage, pheasant populations rose by 22 percent. Certainly losses of this same magnitude can be expected with the withdrawal of land from the Conservation Reserve Program and will be detrimental to pheasants, especially in states such as Minnesota and Iowa where CRP acres provide virtually all of the pheasants' habitat. Changes in a new farm bill 
may rejuvenate the CRP, but new signups (if there are any) are not anticipated until at least 2010 (Forman 2008) and will not happen at all unless CRP soil rental rates are updated to become more competitive with cropland rental prices (Hauck and Nomsen 2008).

South Dakota lost 214,000 acres, or 14 percent, of its total CRP acreage in 2007 and 2008 (Ducks Unlimited 2008). Contracts set to expire between 2008 and 2010 will add another 530,000 acres to that total (Figure 20). This could cause a more significant pheasant loss than the 1960s post-Soil Bank decline because today's agricultural landscape is much less diverse.

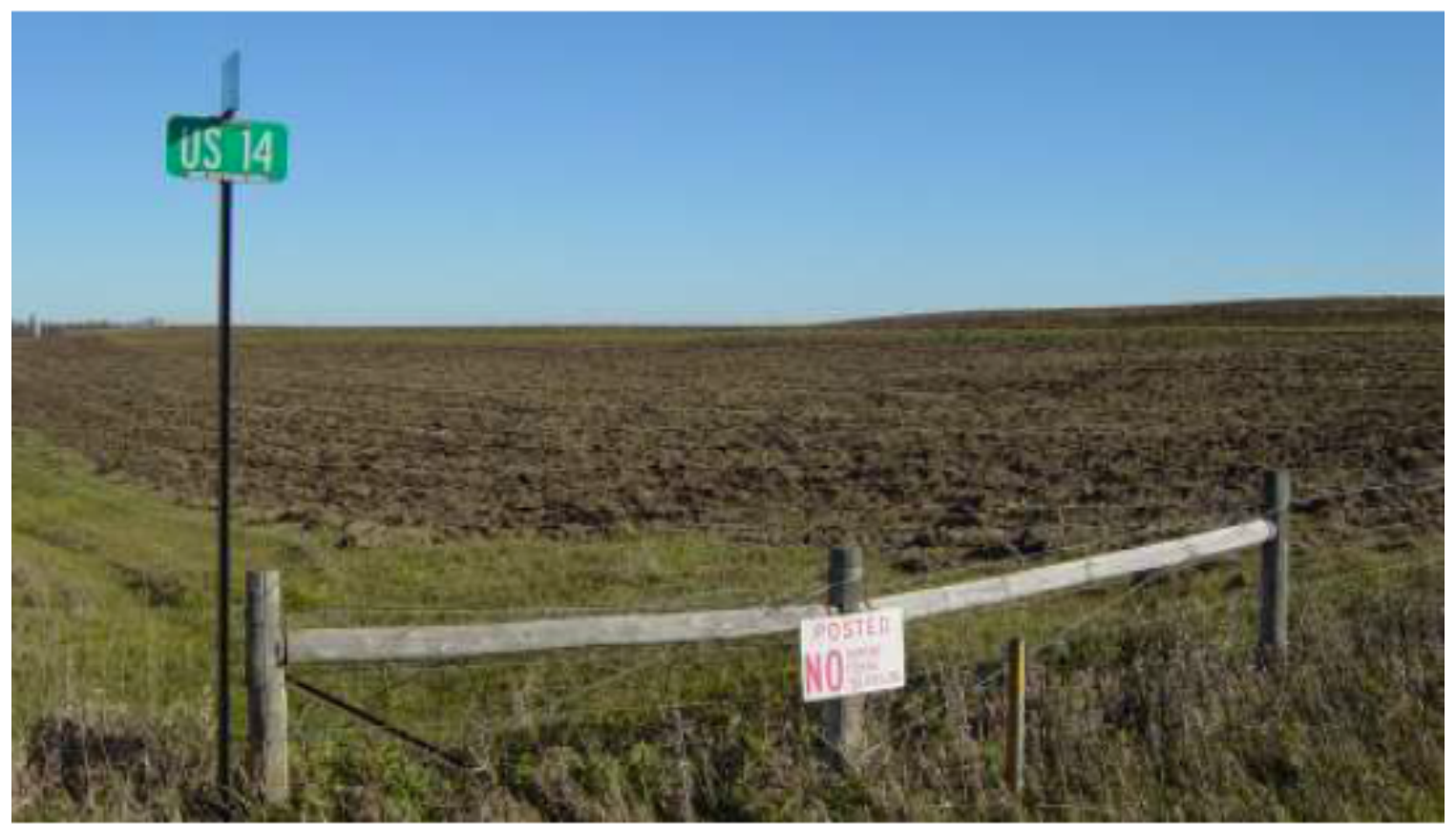

Figure 20: This used to be a CRP field west of Brookings, SD on Highway 14. The grass has been cut, the land has been tilled, and there is field tile waiting just off to the right of this picture ready to be installed so this field can once again produce grain, most likely corn.

If the push towards ethanol (Hallinan 2006) continues to increase in states all across the Midwest, and if the worldwide demand for crops such as corn and wheat continues to increase and drive up commodity prices, payments of CRP contracts cannot compete with cash rental payments. In 2008, late spring floods and crop loss in the Corn Belt states of Iowa, Illinois, and Indiana increased the pressure on marginal states such as South Dakota to produce even more corn. During the last 18 years, cash rental rates have steadily increased in eastern South Dakota, while CRP payments have risen only slightly. Increased crop yields, shifts to higher valued crops of corn and soybeans, and declining input costs left farmers with more money to bid into land rental payments, which helped increase the amount of money per acre a landowner could get by renting out his land versus putting it into a ten or 
fifteen year CRP contract (Janssen 2008). In eastern South Dakota, landowners can earn $\$ 90$ per acre renting the land to a neighboring farmer versus receiving a $\$ 65$ per acre CRP payment.

Conservationists recently convinced the USDA not to initiate a program that would take more CRP land out of conservation than the amount set to expire annually. Such "early-outs" would have given landowners the opportunity to make more money farming their land than they were getting by leaving it in the CRP and had enraged many conservation organizations, such as Pheasants Forever and Ducks Unlimited. In late July 2008, the USDA announced that they would offer no earlyouts.

The question now is, what will be the future of pheasants and pheasant hunting in South Dakota? Will agriculture outcompete conservation? Early indicators say yes. Upland game biologists understand the relationships between the human and natural systems that affect pheasants and thus pheasant hunting. What cannot be accurately predicted are weather events such as blizzards and abnormal spring temperatures or rainfall. There is, however, no question that declines in habitat like those presently happening will only serve to amplify any negative impacts caused by Mother Nature. The future of pheasants and pheasant hunting may be decided by federal agricultural policy and international energy prices as much as by climate.

\section{Acknowledgments}

I would like to thank Roger Auch, Scott Deaner, Matt Gerike, Lisa Harrington, Darrell Napton, and David Scallan, as well as the editor and anonymous reviewers for their helpful and substantive critiques of earlier versions of this manuscript.

1 The gap between non-resident and resident hunters becomes even more impressive when one takes into account that non-residents can only hunt during two five-day periods during an eighty-day season (unless they are hunting on "preserves," which are discussed later in the paper), whereas residents can hunt eighty days plus three days during an early resident-only season.

2 When road hunting, one of the tricks-of-the-trade is to roll down your window and listen for the pheasants. If the roadside grass is dry, the sound a startled pheasant makes while trying to scurry away unseen (a "swishing" sound) is often audible to the driver. As a first line of defense a pheasant will run and will only take flight as a last resort if it feels cornered.

3 In the 1944, hunters could harvest ten birds, five of which could be hens. This had a large impact on subsequent populations, as there were fewer hens to lay eggs. Hunting males (cocks) under current bag limit conditions has no impact on the next year's population as one male will breed with upwards of ten females (Haroldson 2008). The last year that it was legal to harvest hens was in 1947. During the late 1950s and early 1960s, bag limits again went up to five birds during the pheasant 
friendly Soil Bank years, but since then bag limits have been either two or three cock pheasants per day, with the limit today being three.

\section{$\underline{\text { References }}$}

Bangsund, D. A., N. M. Hodur, and F. L. Leistritz. 2004. Agricultural and Recreational Impacts of the Conservation Reserve Program in Rural North Dakota, USA. Journal of Environmental Management 71:293-303.

Berg, J.M. 2006. Minnesota Lawyer. Pers. comm. 7 April 2006.

Coughlin, P. 2008. Wildlife Habitat Program Administrator, South Dakota Department of Game, Fish, and Parks. Pers. comm. 11 August 2008.

Ducks Unlimited. 2008. Loss of CRP and Native Grassland Acres Could Doom Duck and Pheasant Populations. 14 January 2008. [Http://www.ducks.org/blogs/Default.aspx?blogID=1\&blogEntryID=162].

Edwards, W. R. 1994. Agriculture and Wildlife in the Midwest. In Sustainable Agriculture in the American Midwest, edited by G. McIsaac and W.R. Edwards. Chicago: University of Illinois Press.

Eggebo, S. L., K F. Higgins, D. E. Naugle, and F. R. Quamen. 2003. Effects of CRP Field Age and Cover Type on Ring-Necked Pheasants in Eastern South Dakota. Wildlife Society Bulletin 31(3): 779-785.

Erickson, R. E., and J. E. Wiebe. 1973. Pheasants, Economics, and Land Retirement Programs in South Dakota. Wildlife Society Bulletin 1(1): 22-27.

Farmham, A. 1992. A Bang That's Worth Ten Billion Bucks. Fortune 125(5). Viewed using Expanded Academic ASAP, Kansas State University

Forman, K. 2008. U.S. Fish and Wildlife Service. Pers. comm. 20 February 2008.

Graesser, J. 2008. The Impact of Ethanol on Land Use in the Northwestern Corn Belt. Master's thesis, South Dakota State University.

Hallinan, J. T. 2006. A Pheasant Boom lifts Farm Fortunes on Great Plains. Wall Street Journal, 17 November.

Haroldson, K. 2008. Solving the Habitat Puzzle for Pheasants and Other Upland Wildlife. Presented at the 2008 National Pheasant Fest, St. Paul, Minnesota, January 19.

Hart, J. F. 1991. The Land That Feeds Us. New York: W. W. Norton and Company. 
Hauck, A, and D. Nomsen. 2008. CRP Survives Early Outs Talk, but Soil Bank Tragedy Looms. Pheasants Forever. [http://www.pheasantsforever.org].

Janssen, L. 2008. Professor, Department of Economics, South Dakota State University. Pers. comm. 10 March 2008.

Janssen, L., B. Pflueger, and T. Ahrendt. 2007. Agricultural Land Market Trend, 19912007, South Dakota State University Agricultural Experiment Station.

Klein, N., L. Janssen, G. Taylor, E. Opoku, and M. Holbeck. 2008. Conservation Reserve Program in South Dakota. Economic Commentator No. 500, June 12.

Labisky, R. F. 1976. Midwest Pheasant Abundance Declines. Wildlife Society Bulletin 4(4): 182-183.

Leathers, N., and L.M.B. Harrington. 2000. Effectiveness of Conservation Reserve Programs and Land "Slippage" in Southwestern Kansas. Professional Geographer 52(1): 83-93.

Merry, W. 2003. A South Dakotan had a Vision for a Resort that Combined WorldClass Golfing with Pheasant Hunting and Fishing in the Middle of the State. Sioux Falls Argus Leader. 6 July (1A).

Nielson, R. M., L. L. McDonald, J. P. Sullivan, C. Burgess, D. S. Johnson, and S. Howlin. 2006. Estimating response of the ring-necked pheasant (Phasianus colchicus) to the Conservation Reserve Program. Technical report prepared for US Department of Agriculture Farm Service Agency, Contract Number 53-3151-5-8059.

Pheasants Forever. 2008. Pheasants Forever 2008 Pheasant Population Forecast. [http://www.pheasantsforever.org/page/1/2007forecast.jsp].

Ristau, J. 2007. Blizzard Survival Area: Building Woody Cover Shelterbelts for Pheasants. Pheasants Forever 23(1): 48-50.

Ryan, M.R., L.W. Burger, E.W. Kurzejeski. 1998. The impact of CRP on avian wildlife: a review. Journal of Production Agriculture 11(1): 61-66.

Shouse, B. 2004a. Hunters Pay More for Pheasant Acres. Sioux Falls Argus Leader. 21 November $(1 \mathrm{~A})$.

-----2004b. Ruling Limits Road Hunting. Sioux Falls Argus Leader. 2 December (1A).

-----2003. Businesses Network Over Pheasant Hunts. Sioux Falls Argus Leader. 9 October $(1 \mathrm{~A})$. 
Smith, B. 2008. South Dakota Department of Game, Fish, and Parks. Pers. comm. 19 February 2008.

South Dakota Game, Fish, and Parks. 2008a. Pheasant Economics 2007. [http://www.sdgfp.info/Wildlife/hunting/Pheasant/Economics.htm].

-----2008b. Pheasant Statistics 2007.

[http://www.sdgfp.info/Wildlife/hunting/Pheasant/Stats.htm]

Pheasant Management.

[http://www.sdgfp.info/Wildlife/hunting/Pheasant/ManagementQ\&A.htm].

Information on Private Shooting Preserves.

[Http://www.sdgfp.info/Wildlife/hunting /Preserves/PreserveIndex.htm].

Trautman, C.G. 1982. History, Ecology and Management of the Ring-Necked Pheasant in South Dakota. Pierre, South Dakota: Department of Game, Fish, and Parks.

United States Department of Agriculture. 2008a. Active and Expiring CRP Acres by State. [http://content.fsa.usda.gov/crpstorpt/rmepegg/MEPEGGR1.HTM].

National Agricultural Statistics Service, 2002 Census of Agriculture County Profile: Jackson County, Minnesota.

[http://www.nass.usda.gov/census/census02/profiles/mn/cp27063.PDF].

National Agricultural Statistics Service, 2002 Census of Agriculture County Profile: Gregory County, South Dakota.

[http://www.nass.usda.gov/census/census02/profiles/sd/cp46053.PDF].

United States Fish and Wildlife Service. 2008a. 1991 National Survey of Fishing, Hunting, and Wildlife-Associated Recreation, Table B-2.

[http://www.census.gov/prod/1/gen/interior/b.pdf].

1996 National Survey of Fishing, Hunting, and Wildlife-Associated Recreation. [http://library.fws.gov/nat\%5fsurvey1996.pdf].

2001 National Survey of Fishing, Hunting, and Wildlife-Associated Recreation. [http://library.fws.gov/nat\%5fsurvey2001.pdf].

2006 National Survey of Fishing, Hunting, and Wildlife-Associated Recreation. [http://library.fws.gov/nat\%5fsurvey2006.pdf].

Americas National Wildlife Refuge System: What are Waterfowl Production Areas? [http://www.fws.gov/refuges/faqs/WPAs.html]. 
Vandel III, G. M., and R. L. Linder. 1981. Pheasants Decline but Cover-Type Acreages Unchanged on South Dakota Study Area. Wildlife Society Bulletin 9(4): 299-302.

Winter, T. C., and D. O. Rosenberry. 1998. Hydrology of Prairie Pothole Wetlands During Drought and Deluge: A 17-Year Study of the Cottonwood Lake Wetland Complex in North Dakota in the Perspective of Longer Term Measured and Proxy Hydrological Records. Climate Change 40: 189-209.

Woster, K. 2006. Pheasant Hunting Fits This Ranch. Successful Farming 104(5): 48.

-----2001a. Security Not Slowing Pheasant Hunters. Sioux Falls Argus Leader. 27 September $2001(1 \mathrm{~A})$.

Pheasants Bring Millions of Dollars to South Dakota, But Weather Can Cut Into Populations and Profits. Sioux Falls Argus Leader. 26 January 2001 (1A).

-----1999. Pheasants Cash Crop for Many Farmers. Sioux Falls Argus leader. 30 May 1999 (1C). 